\title{
10 Leasing Tips for Optometry Tenants
}

\author{
By Jeff Grandfield and Dale Willerton - The Lease Coach
}

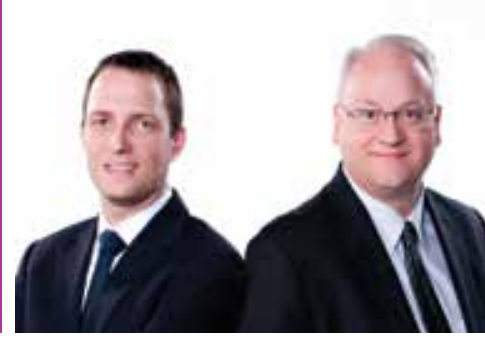

Dale Willerton is the founder of The Lease Coach and Jeff Grandfield recently joined him as partner. Dale and Jeff are commercial lease consultants who work exclusively for tenants, and are also professional speakers and co-authors of Negotiating Commercial Leases and Renewals For Dummies. Got a leasing question? Need help with your new lease or renewal?

Call1-800-738-9202,emailDaleWillerton@TheLeaseCoach.com,orvisitwww.TheLeaseCoach. com. For a copy of our free CD, Leasing Dos \& Don'ts for Commercial Tenants, please email your request to DaleWillerton@TheLeaseCoach.com.
$\mathrm{N}_{\mathrm{p}}^{\mathrm{cota}}$ ew and existing optometry tenants will specialize in proper patient care, but may fall short in knowing about their own commercial leases. Many optometry tenants in fact will either blindly sign a commercial lease document or a lease renewal without completely reading it, trust the landlord to charge a 'fair rental rate,' and/or fear asking what may seem like too many questions. As we emphasize in our new book, Negotiating Commercial Leases \& Renewals For Dummies, the commercial lease is a binding legal document and not fully knowing or understanding what you are signing (and agreeing to ...) can be a serious mistake as you may sign for an inappropriate lease term, miss out on valuable tenant inducements offered by the landlord, and agree to pay too much monthly rent.

Before you sign a commercial lease or a renewal, know what you are getting into and look before you leap. Here are some proven tips to help get you the best commercial lease deal possible:

Negotiate to Win: This should be the goal of the optometry tenant. Why? Because this is the goal of the landlord, the landlord's property manager, and the landlord's real estate agents. The landlord is not necessarily looking for a "win-win" lease deal (thereby benefitting all parties ...). Instead, a typical landlord charges the tenants as much rent as possible and who would expect anything less?

Optometry tenants may mistakenly think that landlords set their rental rate based on what they think the tenants can afford to pay. But landlords really set rental rates based on the cash flow they need to service their mortgage, manage the property, and make a profit. The problem is rather than negotiating to win, most tenants are simply negotiating not to lose. This happens for several reasons including a lack of experience, knowledge, and time. Tenants may often face a fear of rejection (with asking for what they want) as well.
Whether you are negotiating your first commercial lease or a lease renewal, don't rely on the landlord to give you what you deserve. With effective negotiation, many benefits may be available to optometry tenants - these include the lowest possible monthly rental rate, the longest free rent period, the most signage and/or parking, and the biggest tenant allowance.

Negotiate All Lease Terms at Once: Resist the urge to look at your lease as a list of individual points that must be all negotiated separately. All the business terms contained in your lease are connected and must be negotiated collectively. For example, don't agree to the rental rate until you agree to the length of the lease term.

\section{Don't Telegraph Your Intentions or Give Buying Signals:} What we mean here is to check your emotions and what you say when dealing in commercial real estate. To explain, if you're planning to open another location or relocate your practice and your prospective new landlord (or his real estate agent) asks you what you're paying now in your current location, be aware that this is a loaded question. If you're paying $\$ 28.00$ per square foot in your current location but they were only going to ask $\$ 23.00$ per square foot, they could well increase that rental rate because they think that you can afford to pay it. Also, if a tenant reveals somehow that emotionally or mentally he's already decided to renew his current lease - or, if during a space showing, your business partner is gushing over how nice it all is and how perfect the space would be for you, then get ready to pay a higher rent.

Protect Yourself by Incorporating: There are a couple of good reasons to incorporate or form a limited liability company (LLC) if you're about to go into business and lease a commercial location. Businesses fail, often through no fault of the business owner, and incorporation can help protect you. 
If you allow the landlord to put your personal name as the tenant on the lease agreement (or even the letter of intent or offer to lease), then you are personally responsible for rent payments and all other terms of the lease agreement. By incorporating, you are generally off the hook personally and transfer these obligations to the tenant corporation.

Change the Day Your Rent is Due: For many small businessowners, the end of the month is not a pleasant time. Staff payroll, loan payments, and commercial rent are all due. Sometimes having a few days' grace period to make the monthly rent payment can make a world of difference. The Lease Coach often negotiates with the landlord to change the tenant's rental payment date (from month end to perhaps the fifth or tenth day of the following month). If you're successful getting the landlord to agree to this proposal, make sure you get it in writing in the lease or a proper lease-amending agreement stating it.

Creatively Build on Your Relationship with the Landlord: Making deposits to your relationship with your landlord can be invaluable. When you think about it, the tenant is the landlord's customer and the landlord should be trying to initiate or sustain a good relationship with the tenant. But because you may only have one landlord, and the landlord may have hundreds of tenants, it often falls to the tenant to build and foster these relationships. As The Lease Coach, we've always leased commercial office space for our business and found doing this can be extremely effective - offer a bottle of cold water on a hot day, wrap up a bottle of "holiday cheer" at Christmas time, and extend plenty of thanks and appreciation for their work.

Ask the Property Manager or Landlord for a Favor: Have you ever agreed to do something you really didn't want to do, but knew the other person would be beholden to you if did it? We have, both personally and professionally, and even in commercial real estate. Simply asking someone for something in which there is no promise of return or benefit to the other party seldom seems to work. But if you ask for a favor and say those magic words, "I owe you one" or promise a specific future benefit, you're more likely to get your favor. Remember to pause after you ask and let them respond. The tendency is to justify or over-explain. Sometimes asking by e-mail is fine, but doing it verbally gives you a chance to provide more details if the property manager doesn't fully understand your request (or initially turns you down).
Prepare for Murphy's Law: Anything that can go wrong will go wrong - and at the worst possible time. Emotionally and financially, it pays to plan ahead and try to envision what will go wrong. Say the contractor doesn't get your new space built out in time and you're going to open for business five weeks late. Do you want to be paying rent while you're not open for business? Of course not. In this case, The Lease Coach will often negotiate wording into a tenant's lease agreement so the rent doesn't start until the tenant actually opens for business.

Get Professional Help with the Leasing Process: We've spoken with commercial tenants who were relying on their brother, sister, mother, father, spouse, and/or residential real estate uncle to help them negotiate their leases. Granted, these people may know more about leasing than the average tenant; however, they surely are no experts! A professional lease consultant with a proven track record who earns a living serving commercial tenants is your better choice. This so important that it can be the deciding factor in whether your business succeeds.

For a copy of our free CD, Leasing Dos \& Don'ts for Commercial Tenants, please e-mail your request to DaleWillerton@TheLeaseCoach.com.

Dale Willerton and Jeff Grandfield - The Lease Coach are Commercial Lease Consultants who work exclusively for tenants. Dale and Jeff are professional speakers and co-authors of Negotiating Commercial Leases \& Renewals For Dummies (Wiley, 2013). Got a leasing question? Need help with your new lease or renewal?

Call 1-800-738-9202, e-mail DaleWillerton@TheLeaseCoach.com or visit www. TheLeaseCoach.com.

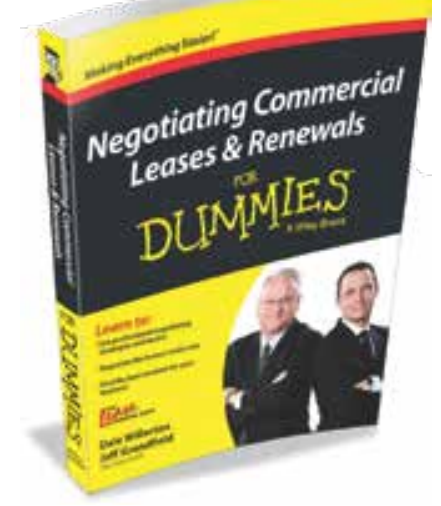

